\title{
Growth response and carcass composition of rabbitfish, Siganus canaliculatus (Park) fed diets supplemented with dehydrated seaweed, Enteromorpha sp.
}

\author{
O. M. Yousif,, ${ }^{1 *}$ M. F. Osman, ${ }^{2}$ A. R. Anwahi, ${ }^{3}$ M. A. Zarouni ${ }^{3}$ and T. Cherian ${ }^{3}$
}

${ }^{1}$ Fish and Shrimp Farming Project-Abu Al Abyad, P.O. Box 372, Abu Dhabi, United Arab Emirates; ${ }^{2}$ Department of Animal Production, Faculty of Agriculture, Ain Shams University, Egypt; ${ }^{3}$ Marine Resources Research Center, Ministry of Agriculture \& Fisheries, Umm Al Qaiwain, United Arab Emirates

\begin{abstract}
A trial to incorporate dehydrated Enteromorpha in the diet of rabbitfish fry averaging 0.25 $\pm 0.04 \mathrm{~g}$ was undertaken for a period of 12 weeks. Four isonitrogenous (39\% crude protein) and isoenergetic $(19 \mathrm{~kJ} / \mathrm{g})$ diets were fed to fish. The dehydrated Enteromorpha was incorporated in the diets at a rate of 0 (control), 10, 20 and $30 \%$. A fifth group of fish was fed control diet and supplemented with known weight of fresh Enteromorpha placed in plastic baskets at the bottom of the rearing tanks. The survival rate, growth performance and feed utilization efficiency were observed to decrease with increasing inclusion levels of dehydrated algae $(\mathrm{p}<0.05)$. The best results of all parameters were achieved by fish fed control diet and fresh Enteromorpha $(\mathrm{P}<0.05)$. Carcass protein was not affected by the different treatments while lipid content was observed to increase in the group of fish supplemented with fresh Enteromorpha $(\mathrm{P}<0.05)$. It is concluded that further studies are needed on the dehydration techniques of Enteromorpha as well as on the digestibility and assimilation of diets containing dehydrated algae.
\end{abstract}

Key words: Enteromorpha, Siganus canaliculatus, growth performance, feed utilization

*Author to whom correspondence should be addressed

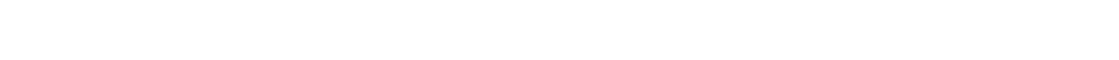 الجري}

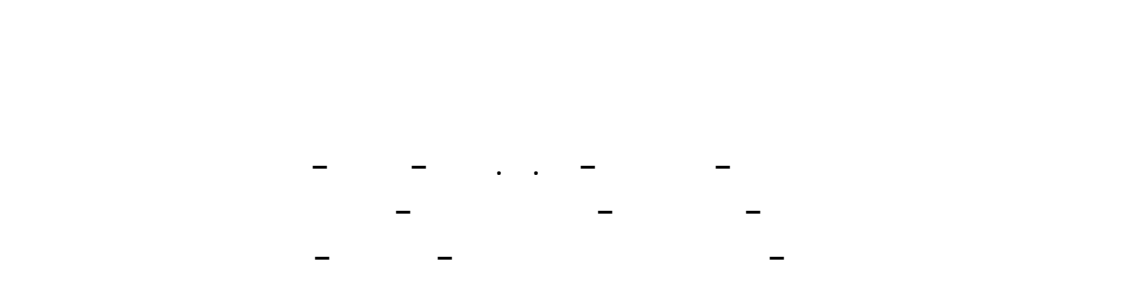

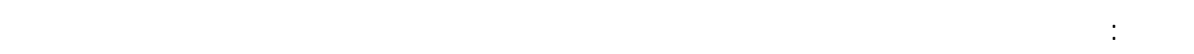

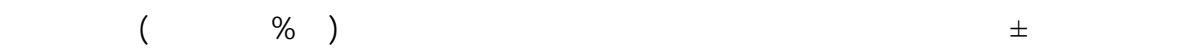

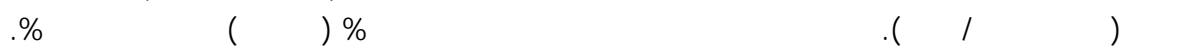

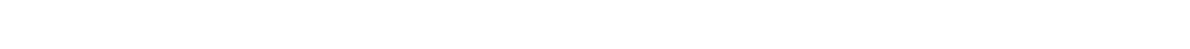

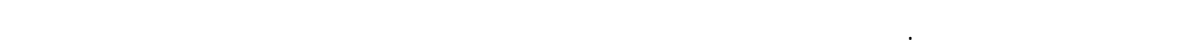

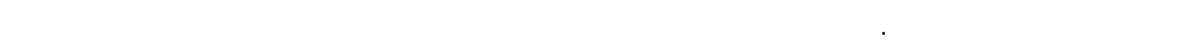

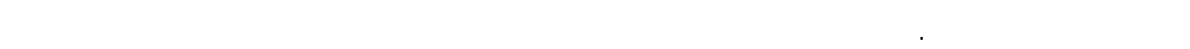

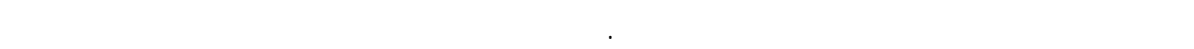
حول ققنيت تجفف طحلب الشبا وكذلك لدرلسة هضم و تمثل العلايق المحتوية على اللشبا المجنف.

$$
\text { كلمات مفتلحية: الشبا ، لمسك الصافي ، أداء النمو ، لستخدلم العلائق }
$$

\section{Introduction}

The potential of siganids for mariculture has been recognized for many years. This potential was attributed to their palatability, hardiness under culture conditions, ability to reproduce easily in captivity and to the fact that the fish are primarily first trophic level feeders and thus can be grown on cheap feeds (BenTuvia et al., 1973; Lam, 1974; Von Westernhagen and Rosenthal, 1976; Tseng 
and Chan, 1982). In the coastal waters of the United Arab Emirates (UAE) two species are found, Siganus canaliculatus, which is the commoner species and one of the most favored food fish; and S. javus, which is less abundant and less valuable (MAF, 1984; Al-Ghais, 1993). The fish is herbivorous, feeding predominantly on filamentous green algae. Early studies of stomach contents and food preference revealed that among the many different algal species and vascular plants eaten, the presence of Enteromorpha was high and was the preferred species. This preference for Enteromorpha by siganids is not directly related to the calorific value of the algae but is related to the texture of its thalli which are crispy and thin (Von Westernhagen, 1973; 1974). Enteromorpha is one of the most widespread genera of the green algae with a long history of food use, both for humans and animals (Jeong et al., 1993). The alga is rich in minerals, carbohydrates and vitamins (Nisizawa et al., 1987; Naidu et al., 1993; Reviers and Leproux, 1993). The alga grows along the coasts of UAE throughout year in the littoral zones exposed to shallow water. The only use of this alga in UAE is that by fishermen as bait to catch siganids (AlGhais, 1993).

Efforts to reduce the cost of fish feed have concentrated on the use of low-cost by-products and plant materials (Yousif et al., 1994). The present study was conducted to evaluate the possibility of utilizing the dehydrated Enteromorpha as a dietary ingredient in the formulated feed for $S$. canaliculatus fry.

\section{Materials and Methods}

Experimental procedure and diets

Rabbitfish fry, S. canaliculatus, were collected by seine netting from Umm Al Qaiwain lagoon and stocked in a 40-t holding concrete tank at the Marine Resources Research Center. The fish were fed a $40 \%$ crude protein formulated diet ad. libitum twice daily. After two weeks of adaptation the fish fry averaging $0.25 \pm$ $0.04 \mathrm{~g}$ (mean \pm s.d.) were randomly distributed in 15 outdoor 1000-L circular fiberglass tanks. The tanks received a continuous flow of filtered sea water $(40 \pm$ $0.5 \%$ ) at a rate of $30 \mathrm{~L} / \mathrm{min}$. The fish were stocked at a rate of 200 fry per tank.

The fresh algae were collected from the seagrass area of Umm Al Qaiwain lagoon and immediately washed with running filtered seawater to remove the epiphytes and other foreign matter such as sand and shells. The algae were then airdried in the sun for two weeks. After complete drying the algae were finely milled using a laboratory mill.

Proximate analysis of major feed ingredients was performed prior to formulation of the experimental diets (Table 1). A lyophilized extract of fresh algae was analyzed for amino acids composition (Table 2).

Table 1. Chemical composition (\% DM basis) of major feed ingredients

\begin{tabular}{lcccc}
\hline & Fish meal & soybean meal & wheat flour & Dehydrated algae \\
\hline Dry matter & 89.84 & 93.27 & 89.34 & 91.65 \\
Crude protein & 72.89 & 55.28 & 14.34 & 11.02 \\
Crude lipid & 11.50 & 1.93 & 3.23 & 0.90 \\
Crude fibre & 0.38 & 7.16 & 0.62 & 8.97 \\
Ash & 8.88 & 8.29 & 0.97 & 18.34 \\
NFE $^{1}$ & 6.35 & 27.34 & 80.84 & 60.77 \\
\hline
\end{tabular}

1 Nitrogen - free extract $=100-($ crude protein + lipid + fibre + ash $)$ 
Emir. J. Agric. Sci. 2004. 16 (2): 18-26

http://www.cfs.uaeu.ac.ae/research/ejas.html 
Table 2. Amino acid composition of fresh Enteromorpha (g $100 \mathrm{~g}^{-1}$ dry weight)

\begin{tabular}{lllr}
\hline Essential & & Non-essential & \\
\hline Arginine & 4.5 & Alanine & 12.5 \\
Histidine & 1.6 & Aspartic acid & 14.7 \\
Isoleucine & 5.0 & Cysteine & 3.0 \\
Leucine & 7.5 & Glutamic acid & 14.2 \\
Lysine & 4.6 & Glycine & 5.6 \\
Methionine & 3.1 & Proline & 5.0 \\
Phenylalanine & 3.3 & Serine & 6.0 \\
Threonine & 6.5 & Tyrosine & 2.2 \\
Valine & 7.8 & & \\
\hline
\end{tabular}

Four isonitrogenous $\quad(39 \%$ crude protein) and isocaloric $(19 \mathrm{KJ} / \mathrm{g})$ test diets were formulated (Table 3). The ingredients of each experimental diet were thoroughly mixed with water and oil in a laboratory feed mixer (Nakayasu Co., Japan) until a uniformly moist mixture was obtained. Pellets were made by passing the diet mixture through a laboratory feed pelletizer (Fuji Mzuho, Model 52-k, Japan) equipped with a 1-mm die. The pellets were then air-dried for 48 hours. The dry pellets of each experimental diet were packed in sealed plastic bags and stored in a freezer at $-20^{\circ} \mathrm{C}$ until used. A fifth group of fish was fed a control diet with addition of a known weight of fresh Enteromorpha placed in plastic baskets at the bottom of the rearing tanks (treatment 4 ).

Each experimental diet was fed to triplicate tanks of fish fry for a period of 12 weeks. The fish were fed three times at a rate of $7 \%$ body weight per day. Fish from each tank were bulk weighed biweekly and the daily feed allowance was adjusted accordingly. At the start and end of the experiment, fish were retained from each treatment for subsequent proximate analysis. 
Table 3. Formulation and chemical composition of the experimental diets

\begin{tabular}{lcccc}
\hline \multirow{2}{*}{ Ingredients (\% as fed) } & \multicolumn{4}{c}{ Diet } \\
\cline { 2 - 5 } & Control & $\mathbf{1}$ & $\mathbf{2}$ & $\mathbf{3}$ \\
\hline Fish meal & 27.0 & 27.0 & 27.0 & 27.0 \\
Soybean meal & 22.0 & 22.0 & 22.0 & 22.0 \\
Wheat flour & 45.0 & 35.0 & 25.0 & 15.0 \\
Dehydrated algae & - & 10.0 & 20.0 & 30.0 \\
Sunflower oil & 4.0 & 4.0 & 4.0 & 4.0 \\
vitamin-mineral mix & 1.0 & 1.0 & 1.0 & 1.0 \\
Carboxymethyl cellulose & 1.0 & 1.0 & 1.0 & 1.0 \\
& & & & \\
Proximate analysis (\%DM) & & & & \\
$\quad$ Dry matter & 88.01 & 86.94 & 85.88 & 85.00 \\
Crude protein & 39.40 & 39.58 & 39.41 & 39.81 \\
Ether extract & 9.31 & 9.48 & 8.93 & 7.36 \\
crude fibre & 3.81 & 3.76 & 3.16 & 3.03 \\
Ash & 7.08 & 11.53 & 15.96 & 20.39 \\
NFE & 40.40 & 35.65 & 32.54 & 29.41 \\
$\quad$ GE (kJ/g diet) & 2 & 19.21 & 18.41 & 17.37 \\
\hline
\end{tabular}

${ }^{1}$ vitamin-mineral mix: shrimp tonic, JV Marine East, Co. Ltd., Taiwan (A 30,000,000 IU, $\mathrm{D}_{3}$ $12,000,000 \mathrm{IU}, \mathrm{B} 1250 \mathrm{mg}, \mathrm{B}_{2} 12,000 \mathrm{mg}, \mathrm{B}_{6} 1250 \mathrm{mg}, \mathrm{B}_{12} 4250 \mathrm{mg}, \mathrm{E} 12,500 \mathrm{mg}, \mathrm{K}$ 5000mg, C $50,000 \mathrm{mg}$, Nicotinmide $30,000 \mathrm{mg}$, $\mathrm{CaO}$ panthotecat $15,000 \mathrm{mg}$, Folic acid $1500 \mathrm{mg}$, Niacinamide $20,000 \mathrm{mg}$, Insitol 112,500 mg, Lecithin 25,000 $\mathrm{mg}$ and Cholin 37,500 mg)

${ }^{2}$ Gross energy calculated based on the conversion factors: protein $23.51 \mathrm{~kJ} / \mathrm{g}$, fat $39.75 \mathrm{~kJ} / \mathrm{g}$ and carbohydrates (as NFE) $17.20 \mathrm{~kJ} / \mathrm{g}$ (Yousif et al.,1996).

\section{Analytical Methods}

Analysis for chemical composition of feed ingredients, experimental diets and fish carcass were made according to the standard methods of AOAC (1984).

Survival rate, weight gain, specific growth rate (SGR), feed conversion ratio (FCR), protein efficiency ratio (PER), protein productive value (PPV) and energy utilization (EU) were calculated as follows:

Survival rate $(\%)=100[($ final number of fish) - (initial number of fish) / (initial number of fish)]

Wt. Gain $(\%)=100$ [(final body wt initial body wt.) /(initial wt.)]

SGR $(\% /$ day $)=100[(\log$ final body wt. - log initial body wt.) / ( time, days)]
$\mathrm{FCR}=[$ feed fed (dry wt., g) $] /[$ fish wt. gain (fresh wt., g)]

PER $=$ [fish wt. gain (fresh wt., g) $] /$ [protein fed $(\mathrm{g})]$

PPV $(\%)=100[$ (final body protein, $g)$ -(initial body protein, g) / (protein intake, g)]

$\mathrm{EU}(\%)=100[($ final body energy, $\mathrm{kJ})$ -(initial body energy, kJ) / (energy intake, $\mathrm{kJ})$ ]

\section{Statistical Analysis}

All values are reported as means \pm SEM. Performance and carcass composition means were compared using the MSTAT 4 package (Nissen, 1987). Duncan's multiple range test of the same program was used to test for differences among treatment means at $\mathrm{P}<0.05$. 


\section{Results and Discussion}

The comparison of growth response and feed performance of $S$. canaliculatus fed the experimental diets is shown in Table 4. Survival, weight gain, specific growth rate, feed conversion ratios, protein efficiency ratio, protein productive value and energy utilization of fish fed the control diet supplemented with fresh algae were significantly better $(\mathrm{P}<0.05)$ than those of fish fed diets including various levels of dehydrated algae. All these parameters were observed to decrease with increasing inclusion levels of the dehydrated algae $(\mathrm{P}<0.05)$. The poorest performance $(\mathrm{P}<0.05)$ was observed in the group of fish receiving diet supplemented with $30 \%$ dehydrated algae. The carcass composition (Table 5) showed no significant differences $(\mathrm{P}<0.05)$ in the body moisture and protein content among all treatments. The lipid and energy contents were higher $(\mathrm{P}<0.05)$ in the fish fed the control diet and fresh
Enteromorpha whilst the values of other treatments decreased with increasing the level of inclusion of dehydrated algae. The lowest $(\mathrm{P}<0.05)$ ash content was produced by fish fed the control diet supplemented with fresh Enteromorpha sp.

When comparing the chemical composition of local Enteromorpha sp. used in this study with those from other countries (Nisizawa et al., 1987; Naidu et al., 1993), it is found that local algae have a lower protein content and high carbohydrate level. The lipid and fibre contents do not differ from those reported elsewhere. The amino acid composition indicated that the green algae used in this study are poor in histidine, tyrosine, methionine and cystine and rich in aspartic acid, glutamic acid and alanine. This tendency was reported by other workers for Enteromorpha. (Amano and Noda, 1992). Nevertheless, these values fall within the recommended ranges for finfishes (NRC, 1983; De Silva and Anderson, 1995).

Table 4. Performance of $S$. canaliculatus fry fed the experimental diets

\begin{tabular}{lrrrrrr}
\hline & \multicolumn{7}{c}{ Diet } \\
& \multicolumn{1}{c}{ Control } & \multicolumn{1}{c}{$\mathbf{1}$} & \multicolumn{1}{c}{$\mathbf{2}$} & $\mathbf{3}$ & $\mathbf{4}^{*}$ & \multicolumn{1}{c}{ \pm SEM } \\
\hline Initial weight (g) & $0.25^{\mathrm{a}}$ & $0.25^{\mathrm{a}}$ & $0.26^{\mathrm{a}}$ & $0.25^{\mathrm{a}}$ & $0.25^{\mathrm{a}}$ & 0.040 \\
Final weight (g) & $2.82^{\mathrm{b}}$ & $2.83^{\mathrm{b}}$ & $2.15^{\mathrm{bc}}$ & $1.50^{\mathrm{c}}$ & $4.61^{\mathrm{a}}$ & 0.294 \\
Survival (\%) & $27.00^{\mathrm{b}}$ & $31.00^{\mathrm{b}}$ & $29.00^{\mathrm{b}}$ & $16.00^{\mathrm{c}}$ & $52.33^{\mathrm{a}}$ & 4.069 \\
Weight gain (\%) & $1022.62^{\mathrm{b}}$ & $1034.52^{\mathrm{b}}$ & $724.49^{\mathrm{bc}}$ & $498.67^{\mathrm{c}}$ & $1741.51^{\mathrm{a}}$ & 118.485 \\
SGR (\%/day) & $2.87^{\mathrm{b}}$ & $2.87^{\mathrm{b}}$ & $2.50^{\mathrm{bc}}$ & $2.10^{\mathrm{c}}$ & $3.47^{\mathrm{a}}$ & 0.131 \\
Feed intake (mg/day) & $151.85^{\mathrm{a}}$ & $141.54^{\mathrm{a}}$ & $119.96^{\mathrm{b}}$ & $99.03^{\mathrm{c}}$ & $162.50^{\mathrm{a}}$ & 6.617 \\
FCR & $4.29^{\mathrm{b}}$ & $4.05^{\mathrm{b}}$ & $4.64^{\mathrm{b}}$ & $6.06^{\mathrm{a}}$ & $2.61^{\mathrm{c}}$ & 0.357 \\
PER & $0.80^{\mathrm{b}}$ & $0.85^{\mathrm{b}}$ & $0.79^{\mathrm{b}}$ & $0.63^{\mathrm{b}}$ & $1.32^{\mathrm{a}}$ & 0.071 \\
PPV (\%) & $10.09^{\mathrm{b}}$ & $12.33^{\mathrm{b}}$ & $10.25^{\mathrm{b}}$ & $8.84^{\mathrm{b}}$ & $18.26^{\mathrm{a}}$ & 1.022 \\
EU(\%) & $5.09^{\mathrm{b}}$ & $6.77^{\mathrm{b}}$ & $5.66^{\mathrm{b}}$ & $4.47^{\mathrm{b}}$ & $9.91^{\mathrm{a}}$ & 0.598 \\
\hline
\end{tabular}

Means in the same row having the same superscript are not significantly different $(\mathrm{P}<0.05)$

* Treatment 4: fish fed control diet in addition to fresh algae 
Table 5. Carcass composition of $S$. canaliculatus fry fed the experimental diets

\begin{tabular}{lcllcccc}
\hline & & \multicolumn{7}{c}{ Diet } \\
\cline { 3 - 8 } & Initial & Control & $\mathbf{1}$ & $\mathbf{2}$ & $\mathbf{3}$ & $\mathbf{4}$ & 土SEM \\
\hline Dry matter & 19.50 & $21.65^{*}$ & 23.91 & 22.70 & 22.05 & 23.07 & 0.334 \\
Crude protein & 51.81 & $57.42^{*}$ & 58.66 & 57.54 & 60.61 & 58.06 & 0.529 \\
Crude lipid & 7.57 & $15.50^{\mathrm{bc}}$ & $17.11^{\mathrm{b}}$ & $13.06^{\mathrm{c}}$ & $8.03^{\mathrm{d}}$ & $21.55^{\mathrm{a}}$ & 1.260 \\
Ash & 35.38 & $18.61^{\mathrm{b}}$ & $18.23^{\mathrm{bc}}$ & $20.28^{\mathrm{ab}}$ & $21.88^{\mathrm{a}}$ & $15.95^{\mathrm{c}}$ & 0.600 \\
Energy content $(\mathrm{kJ} / \mathrm{g})$ & 15.26 & $19.74^{\mathrm{bc}}$ & $20.66^{\mathrm{b}}$ & $18.79^{\mathrm{cd}}$ & $17.52^{\mathrm{d}}$ & $22.29^{\mathrm{a}}$ & 0.471 \\
\hline
\end{tabular}

Means in the same row having the same superscript are not significantly different $(p<0.05)$

${ }^{*}$ Means in this row are not significantly different $(p<0.05)$

Ash content was observed to increase with increasing levels of dehydrated algae in the diets. This was probably due to the presence of sand grains and shells or sea salts resulting from the inadequate washing of the algae. Jauncey and Ross (1982) recommended a level of less than $10 \%$ in the diets for tilapia. Ash per se is not known to be harmful to cultured organisms. However, ash content, such as silica, affects the digestibility of the diets (De Silva and Anderson, 1995). Since siganids usually naturally thrive on algae, the ingestion by $S$. canaliculatus of high ash levels contained in the experimental diets might not be the direct cause of growth retardation. A possible cause could be the drying process of the algae followed in this study. The sun-drying technique might have affected the nutritional properties of the algae as well as its palatability. The presence of high antinutritional factors in the dehydrated algae might have also affected the growth of the fish. Naidu et al. (1993) attributed the growth retardation of rats fed seaweed meal, among which was Enteromorpha sp., to the presence of lectins (haemagglutinins). Lectins are proteins which bind to specific receptor sites in the intestinal epithelial cells resulting in impairment of nutrient absorption (Naidu et al., 1993; De Silva and Anderson, 1995)
In the present study, it has been observed that, the fish body color became dark before death and the fish were observed to swim near the water surface, then completely cease feeding. These symptoms are characteristic of streptococcal infection described by Foo et al. (1985) in diseased S. canaliculatus. This best survival in the treatment receiving supplement of fresh Enteromorpha was probably due to the antibacterial activity found in the algae. This activity has been widely reported for Enteromorpha spp. and other marine algae (Ballantine et al., 1987; Kumar and Rengasamy, 2000). On the other hand this improved survival rate could be attributed to the qualitative lipid composition of the fresh algae. Enteromorpha, like the other marine green algae, usually contain highly polyunsaturated $\mathrm{C}_{16}$ and $\mathrm{C}_{18}$ fatty acids (Akinin et al., 1992; Jones and Harwood, 1993; Khotimchenko, 1993). The supplementation of dietary unsaturated fatty acid in the diet of marine fish larvae have been reported to improve the survival rate (NRC, 1983; Dhert et al., 1991; Izquierdo, 1996).

In conclusion, the present study shows that the dehydrated Enteromorpha incorporated in the diets of $S$. canaliculatus produced poor growth response and feed utilization efficiency. However, further studies on the digestibility and assimilation of diets 
containing dehydrated algae by $S$. canaliculatus are recommended. Also, further studies are needed to determine the proper techniques of processing the algae. Cooking and vacuum drying of seaweeds has been reported to increase digestibility of the plant (Naidu et al., 1993).

\section{Acknowledgements}

The study was supported by the Scientific Research Council, UAE University and the Ministry of Agriculture and Fisheries. Sincere thanks to Professor K.D. Günther, Institute of Animal Physiology and Animal Nutrition, University of Göttingen, Germany for his kind help in the analysis of amino acids. The help of the staff of the Aquaculture Laboratory, Faculty of Agricultural Sciences, UAE University and Marine Resources Research Center, Umm AL Qaiwain is deeply appreciated.

\section{References}

Akinin, M., P. Moellet-Nzaou, E. Cisse, J. M. Kornprobst., E. M. Gaydou and A. Samb. 1992. Fatty acid composition of twelve species of Chlorophyceae from the Senegalese Coast. Phytochemistry 3(8): 27392741.

Al-Ghais, S. M. 1993. Some aspects of the biology of Siganus canaliculatus in Southern Arabian Gulf. Bulletin of Marine Science 52(3): 886-897.

Amano, H. and Noda. H. 1992. Proteins of protoplasts from several seaweeds. Nippon Suisan Gakkaishi 58(2): 291299.

AOAC. 1984. Official Methods for analysis of the Association of Official Analytical Chemists, $14^{\text {th }}$ edn. AOAC, Arligton, Virginia. 1141pp.
Ballantine, D. L., W. H. Gerwick, S. M. Velez, E. Alexander and P. Guevara. 1987. Antibiotic activity of lipidsoluble extracts from Caribbean marine alge. Hydrobiologia 151/152: 463-469.

Ben-Tuvia, A., G. W. Kissil and D. Popper. 1973. Experiments in rearing rabbitfish (Siganus rivulatus) in seawater. Aquaculture 1: 359-364.

De Silva, S. S. and T. A. Anderson. 1995. Fish Nutrition in Aquaculture. Chapman \& Hall, London. 319pp.

Dhert, P., L. C. Limm, P. Lavens, R. Chou and P. Sorgeloos. 1991. Effect of dietary essential fatty acids on egg quality and larviculture success of the greasy grouper (Epinephelus tauvina, F.): preliminary results. In: P. Lavens, P. Sorgeloos, E. Jaspers, and F. Ollevier (Eds). Larvi 91-Fish \& Crustacean Larviculture Symposium. Special Publication No. 15, European Aquaculture Society, Gent, Belgium.

Foo, J. T. W., B. Ho and T. J. Lam. 1985. Mass mortality in Siganus canaliculatus due to streptococcal infection. Aquaculture 49: 185-195.

Izquierdo, M. S. 1996. Review article: Essential fatty acids requirements of cultured marine fish larvae. Aquaculture Nutrition 2: 183-191.

Jauncey, K. and B. Ross. 1982. A guide to tilapia feeds and feeding. Institute of Aquaculture, Univ. Stirling, Scotland.

Jeong, B. Y., D. M. Cho, S. K. Moon and J. H. Peun. 1993. Quality factors and functional components in the edible seaweeds. 1. Distribution of n-3 fatty acids in 10 species of seaweeds by 
their habitat.. Korean Soc J. Food Nutri. 22(5): 621-628.

Jones, A. L. and J. L. Harwood. 1993. Lipids and lipid metabolism in the marine alga Enteromorpha intestinalis. Phytochemistry 34(4): 969-972.

Khotimchenko, S. V. 1993. Fatty acids of green macrophytic algae from the sea of Japan. Phytochemistry 32(5): 12031207.

Kumar, K. A. and R. Rengasamy. 2000. Antibacterial activities of seaweeds extracts/fractions obtained through a TLC profile against the phytopathogenic bacterium Xanthomonas oryzae pv. oryzae. Botanica-Marina 43 (5): 417-421.

Lam, T. J. 1974. Siganids: their biology and mariculture potential. Aquaculture 3: $325-354$.

MAF (Ministry of Agriculture and Fisheries). 1984. Study on mariculture environment of Umm Al Quwain Lagoon and the experimental rearing of shrimp, rabbitfish and mullet. Technical Report No. 8. Department of Fisheries, United Arab Emirates. 72 pp.

Naidu, K. A., A. Tewari, H. V. Joshi, S. Viswanath, H. P. Ramesh and S. V. Rao. 1993. Evaluation of nutritional quality and food safety of seaweeds of India. J. Food Safety 13: 77-90.

Nisizawa, K., H. Noda, R. Kikuchi and T. Watanabe. 1987. The main seaweed foods in Japan. Hydrobiologia 151/152: 5-29.

Nissen, O. 1987. MSTAT 4 - Michigan State University Statistical Package.
Dept. of Crop and Soil Science, Michigan State University, East Lansing, Michigan.

NRC. 1983. Nutritional Requirements of Warmwater Fishes and Shellfishes. National Research Council, National Academy Press, Washington, DC. 102 pp.

Reviers, B. and A. Leproux. 1993. Characterization of polysaccharides from Enteromorpha intestinalis (L.) Link, Chlorophyta. Carbohydrate Polymers 22: 253-259.

Tseng, W. Y. and K. L. Chan. 1982. The reproductive biology of rabbitfish in Hong Kong. J. World Maricul. Soc. 13: 313-321.

Von Westernhagen, H. 1973. The natural food of the rabbitfish Siganus oramin and S. striolata. Marine Biology 22: 367-370.

Von Westernhagen, H. 1974. Food preference in cultured rabbitfishes (Siganidae). Aquaculture 3: 109-117.

Von Westernhagen, H. and H. Rosenthal. 1976. Some aspects of the suitability of various Philippine siganid species (Siganidae) for mariculture. Aquaculture 9: 297-311.

Yousif, O. M., A. A. Ghaleb, and M. Pessarakli. 1994. Evaluation of dehydrated alfalfa and salt bush (Atriplex) leaves in diets for tilapia (Oreochromis aureus L.). Aquaculture 129: 341-347.

Yousif, O. M., M. F. Osman and G. A. Alhadrami. 1996. Evaluation of dates and date pits as dietary ingredients in tilapia (Oreochromis aureus) diets 
O. M. Yousifet al.

differing in protein sources. Biores. Technol. 57(1): 81-85.

Yousif, O. M., M. F. Osman, A. A. Anawhi and T. Cherian. 1996.
Optimum protein-to-energy ratio for two size groups of rabbitfish, Siganus canaliculatus (Park). Aquaculture Nutrition 2: 229-233. 